Vol.10, Issue 1, pp. 1-16, 2022

Online ISSN: 2054-636X (Online)

Print ISSN: 2054-6351(Print)

\title{
ENHANCING STUDENTS' ACADEMIC INTEREST USING TWO INSTRUCTIONAL MODELS IN CHEMICAL EQUILIBRIUM IN BENUE STATE, NIGERIA
}

\author{
${ }^{1}$ Joel Okwo Ukwuru, ${ }^{2}$ Prof. Joel O Eriba and ${ }^{3}$ Prof. Josiah Ogbeba \\ ${ }^{1}$ Department of Chemistry, College of Education, Oju Benue State, \\ 2 Department of Science and Mathematics Education, Benue State University, Makurdi, \\ ${ }^{3}$ Department of Science and Mathematics Education, Benue State University, Makurdi,
}

\begin{abstract}
The study investigated the effects of 4As and 5Es instructional models on senior secondary II students' interest in chemical equilibrium in Benue State. Two research questions guided the study, while two hypotheses were formulated and tested. The study adopted quasi-experimental, non-randomized control group pretest and posttest design. The population of the study comprised 8,864 SSII Chemistry students. Samples of 194 SSII students from six Government grant aided secondary schools in Benue Education Zone C were selected using multistage sampling techniques. Instrument for the study was Chemical Equilibrium Students' Interest Rating Questionnaire (CESIRQ) with reliability coefficient of 0.70. Analysis using mean, standard deviation and mean gain scores were used to answer the research questions while Analysis of Covariance (ANCOVA) was used to test the hypotheses at 0.05 level of significance. The findings of the study revealed that there was a significant difference in the mean interest rating of students taught chemical equilibrium using 4As, 5Es instructional models and modified lecture method [ $F_{2,193}=89.995 ; P=0.000<0.05$ ]. There is no significant difference in the mean interest rating of male and female students taught chemical equilibrium using $4 A s$ instructional model $\left[F_{1,62}=2.339 ; P=0131<\right.$ 0.05]. There is no significant difference in the mean interest rating of male and female students taught chemical equilibrium using 4As instructional model [ $F$ 1,63 $=3.173 ; P=$ $0.080<$ 0.05].There is no significant interaction effects between instructional models and gender on students interest $\left[F_{2}, 193=.262 ; P=.769>0.05\right]$ when taught chemical equilibrium concepts. The study concludes that 5Es and 4As instructional models have greater effects on students' academic interest in Chemical Equilibrium than Modified Lecture Method on SS II students in Benue Education Zone C. Based on the findings, it was recommended among others that Ministry of Education through Chemistry teachers should emphases the use of 5Es and 4As instructional models in teaching to enhance the academic interest of students in Chemistry.
\end{abstract}

KEYWORDS: 4As, 5Es, Instructional Models, Students' Academic Interest and Chemical Equilibrium.

\section{INTRODUCTION}

The importance of science in advancing national goals and aspirations reveals to a large extent the huge commitment and support which nations make and give to Science and Technology advancement. It is an essential tool for a nation's progress and development (Ajayi, Achor \& Otor, 2020). Students in various institutions are expected to be trained to 
discover, invent and be part of the scientific community and the teachers of science and technology are the channels or agents through which the skills and knowledge get to the learners.

Chemistry is most commonly regarded as the "Central Science" or the "mother of science" owing to its contribution and influence (Agogo \& Otor, 2015). Chemistry is an experimental science that systematically studies the composition, properties and activities of organic and inorganic substances and various elementary forms of matter (Senese, 2013). The relevance of chemistry as a requirement to technological advancement of a nation cannot be underrated (Olorunyomi, 2013). The developed countries make headway by recognizing the relevance of Chemistry in their national economy as it is a core subject in the study of Medicine, Pharmacy, Engineering and several technologically-based courses. Research evidence has proved that Chemistry contributes to quality of life and nation building in all ramifications. Despite the critical role played by chemistry to national development, Nigerian Senior School Certificate Examination (SSCE) has continued to record poor performance in Chemistry over the years (Olorundare, 2014).

Currently, instructional models that are strongly advocated include 4As and 5Es. These two instructional models may be preferred over others because of their effectiveness as reported in literature. This is as a result of the fact that traditional method of teaching science at the secondary school level has been widely implicated for being responsible for the undesirable state of science education in Nigeria by placing emphasis on examinations and certifications rather than understanding of concepts that could lead to outstanding learning outcomes (Onanuga \& Saka, 2018). Researchers have continued to search for appropriate methods and strategies that will enable Chemistry students to gain proper understanding and application of Chemistry concepts and principles that will enhance performance. According to Alamina, (2016), some methods, strategies and models as reported in literature are problem solving, project, field trip, concept mapping, played-way, discovery/inquiry method, Computer Assisted Instruction (CAl), collaborative approach, individualized, Jigsaw, 7Es, 5Es, 4As instructional models to mention but a few.

4As model as one of the independent variable in this study, assumes that individuals construct knowledge by actively relating new information to their personal experience and their current frameworks for making sense of that experience. The four components are to: activate prior knowledge, acquire new knowledge, apply knowledge and assess knowledge. These broad categories, when narrowed down allow teachers to make sure students learn. By activating prior knowledge, students make important connections to past learning and prepare their brains for new content. New content is presented and taught, then applied to real-world or past situations. An assessment is given to determine students' understanding. Each of the four phases of the instructional model provides opportunities for formative and summative assessments of student. In each phase of the A's, teacher hears what students say and observes what students do, and in response to either form of evaluation, adjusts their instructional intentions. Vygotsky (1978) presupposed that in using 4As instructional model individuals construct their own knowledge, develops social relation which provides opportunity to mix with others and it is accompanied through activities carried out socially. 
On 5Es instructional model, the view that students are active thinkers who construct their own knowledge and understanding from interactions with the environment, concepts and other individuals is based on the theory of constructivism. A constructivist view of learning recognizes that students need time to; express their thinking, interact with objects, substances, and equipment to develop a range of experiences on which to base their thinking, reflect on their views by writing and expressing themselves and comparing what they think with what others think, and make links between their learning experiences and the real world.

This instructional model provides a built-in structure for creating a constructivist classroom. The 5Es model arranged learning experiences so that students have the opportunity to construct their own knowledge of a concept over time. The model leads students through five stages of learning that are easily described using words that begin with the letter E namely Engage, Explore, Explain, Elaborate, and Evaluate. According to Bybee and Pamela (2016), 5Es learning model was adopted for learning. The 5Es instructional model was designed to help students' learning by linking prior knowledge to new concepts.

Interest is another vital variable in learning because as a learner becomes interested in a given activity; he/she is likely to be more actively involved. Danjuma (2015) opined that interest is an important aspect in the learning process. This is because it helps in sustaining concentration, purpose commitment and cooperation with the teacher in the teaching and learning processes. Interest is an emotional factor that has a principal function in learning any given task. The place of interest in a learner cannot be overemphasised especially as it affects the choice of learning. It has been discovered that the innate intellectual potential in many learners may not be realised until their interest is aroused. Activation of interest in learners during the learning process makes learning to be exciting and full of fun. This then implies that, so long as the learners interest is sustained by the teacher meaningful learning will continue to occur.

According to Abande (2010), interest is a state of curiosity or concern about something or the attention given to something. If a student demonstrates a higher interest in a course, this will help him to put in more effort, time and energy in learning which will in turn lead to higher performance (Godspower-Echie \& Ihenko, 2017). Interest is an indispensable force for achievement in any given school execution of a programme. Interest as a crucial factor in students' performance in chemistry is referred to as a differential likelihood of investing in one form of stimuli rather than the other.

Chemical equilibrium is a theory which explains chemical reactions based on three ideas: incomplete reactions, reversibility and dynamism (Quilez, 2019). The theory maintains that in a closed system, reactants are not completely used up to form products; but that as products are formed, they decompose to form back reactants. The two opposing reactions occur continuously, even when at the observable level no reaction seems to be happening. Studies on students' understanding of Chemical equilibrium worldwide have revealed a number of limitations to learning of chemical equilibrium. These limitations include students' alternative conception relating to the nature of chemical equilibrium and poor understanding of equilibrium law, confusion between rate and equilibrium and poor understanding of the effects of catalysis, temperature and concentration on equilibrium reactions (Ozmen, 2018). 
Secondary schools in Nigeria are mostly mixed schools consisting of male and female students and therefore the performance of students in chemical equilibrium is a sum total of individual scores of both male and female students. In Nigeria gender and cultural issues are inseparable variables that create sex role stereotypes as the basis for socio-cultural classification of human activities as determined by the society. The indiscriminate assigning of roles to male and female with different expectations by the society has made science as masculine in nature. According to Agbidiye (2012), the demographic statistics of Benue State has revealed that the population of males and females is nearly equal, as can be seen in 2006 Census figures (males, 2,144,043 \& females, 2,109,598). In spite of this, the enrolment of females in science, mathematics and technology (STM) related courses such as medicine, architecture among others, is still very low compared to males.

\section{Statement of the Problem}

The Nigerian educational sector has a lot of challenges as there are consistent cases of lack of interest of students in chemistry in external examinations such as the West African Examinations Council (WASSCE), National Examinations Council (NECO), General Certificate Examinations (GCE), and Unified Tertiary Matriculation Examinations (UTME). Federal and State Ministry of Education, Science and Technology, School administrators, parents and researchers, are worried about poor performance of students in SSCE and NECO as this has deprived such students' opportunities of gaining admission into higher institutions of learning to read science and science related professional courses such as medicine, pharmacy, and engineering.

Students lack of interest, learning difficulties and misconceptions in chemical equilibrium are indications of the likelihood of a deficiency in instructional strategies used in chemistry instruction. It has been observed that the conventional teaching methods such as lecture and discussion methods adopted in the classroom have not provided the varied activities or stimulated students learning. Currently, the conventional method of instruction being used in chemistry teaching has not yielded considerable improvements in the quality of students' interest in the subject. The problem posed as a question therefore is, would the use of 4As and 5Es instructional models improve students' academic interest in chemical equilibrium?

\section{Research Questions}

The following research questions will guide the study:

1. What are the mean interest ratings of students in Chemical equilibrium when taught using 4As, 5Es instructional models and those taught using modified lecture method?

2. What is the difference in the mean interest ratings of male and female students taught chemical equilibrium using 4As instructional model?

3. What is the difference in the mean interest ratings of male and female students taught chemical equilibrium using 5Es instructional model?

4. What are the interaction effects between instructional models and gender on students' interest in chemical equilibrium?

\section{Hypotheses}

The following null hypotheses will be tested at 0.05 level of significance. 
Vol.10, Issue 1, pp. 1-16, 2022

Online ISSN: 2054-636X (Online)

Print ISSN: 2054-6351(Print)

1. There is no significant mean difference in interest rating of students in chemical equilibrium taught using 4As, 5Es instructional models and those students taught using modified lecture method.

2. There is no significant difference between the mean interest rating scores of male and female students taught chemical equilibrium using 4As instructional model.

3. There is no significant difference between the mean interest rating scores of male and female students taught chemical equilibrium using 5Es instructional model.

4. There is no significant interaction effect between instructional models and gender on students' interest in chemical equilibrium.

\section{Significance of the Study}

This study may be significant in several ways to the following; curriculum planners, students, teachers, school administrators, and researchers. The result obtained from this study would help the curriculum planners to design a worthwhile programme of instruction for students and also for the teachers that are teaching chemistry. The findings could be of immense benefit to the students as it would make them have a better understanding of some basic concepts in chemical equilibrium hence an improvement in their performance in chemistry that will help them gain opportunities in other science related courses.

Results obtained from this study could be beneficial to the students in Colleges of Education, Faculties of Education in Nigerian Universities since references can be made to the available information and could be adapted for their training. The findings of the study could serve as springboard for many authors that want to develop new books for the use of 4As and 5Es instructional models in the teaching of chemistry concepts. The findings of this study could form the basis for further research by chemistry educators as issues that might arise from this study with regards to the variables that could demand further probing which will eventually become a source of problem for research.

\section{Scope of the Study}

This study will focus on effects of 4As and 5Es instructional models on students' interest as a way of teaching and learning chemistry concepts and will be carried out on senior secondary Two Students in Zone C of Benue State, which comprises nine local government areas. The scope of the study is broken down into content scope, subject scope, variable scope and geographical scope. Specifically, the researcher decided to experiment with the use of 4As and 5Es instructional models on the concept of chemical equilibrium because they seems to have the prospect of enhancing the academic interest of chemistry students.

This study was restricted to Senior Secondary School Two students because it is the class that the topic 'Chemical equilibrium' (Nature of dynamic equilibrium, calculations involving equilibrium constant value, effects of concentration on equilibrium, effects of temperature on equilibrium, effects of pressure on equilibrium, effects of adding a solid reactant on equilibrium and interpretation of chemical equilibrium) appears in senior secondary school syllabus. Chemical equilibrium was selected for this study because the West African Examinations Council Chief Examiners' report of 2010 - 2017 has identified it as an area that questions were found difficult by senior secondary school chemistry students. This has made the students to perform poorly in external examination. 


\section{RESEARCH METHOD}

The research design adopted for this study was quasi-experimental design, particularly the non-randomized pre -test post-test control group design. This was used to measure the effects of 4As and 5Es instructional models (independent variables) on SSII students' interest (dependent variables) in chemical equilibrium in Education Zone $\mathrm{C}$ of Benue State. The design involves three groups (two experimental groups and one control group) where subjects were not randomly assigned to the groups by the researcher instead intact classes were used.

The target population of this study is 8,864 SSII students from 99 government grant-aided secondary schools in Benue Education Zone $\mathrm{C}$ that offer chemistry as one of the core subjects. The government grant-aided secondary schools are preferred because their mode of establishment and operation is in line with the State Ministry of Education operational guidelines. The choice of SSII students is based on the assumption which has been confirmed that they have covered chemical equilibrium concepts in chemistry and should understand the concepts better using different instruct The sample size for this study comprised 194 (84 male and 110 female) senior secondary school students in the intact classes to be selected from six co-educational schools. The sample for experimental group I comprise 63 students with (27 males and 36 females), and 64 students (28 males and 34 females) for the experimental group II while the control group has 67 students (30 males and 37 females) respectively. The sample of 194 is considered adequate because in experimental designs fewer subjects are often used as it is easier to observe change within the subjects than differences between groups. It is also argued that in experimental studies less emphasis is placed on large sample size but on the treatment and control of extraneous variables.

Multi-stage sampling was adopted in this study. The large population of the schools was divided into stages to make the sampling process more practical. In order to get the samples using multistage technique, Benue Education Zone $\mathrm{C}$ was divided into Old Oju, Old Otukpo, and Old Okpokwu respectively. At the second stage, each of the chosen zones was further subdivided based on the Local Government they have, then a sample of two Local Government Areas was selected from each zone. At the third stage, selected Local Government Area was broken down to their respective Council wards. At the fourth stage, desired number of schools was selected from the council wards using purposive sampling technique. Purposive sampling technique also referred to as judgemental sampling was used to sample the required schools based on the nature of this study and six schools were assigned randomly to two experimental and control groups. Sampled schools were designated as A, B, C, D, E and F. A \& B was assigned to experimental group I, C \& D was assigned as experimental group II, while school $\mathrm{E}$ and $\mathrm{F}$ was assigned as control group III. The experimental group I was treated with 4As, experimental group II was treated with 5Es while the control group was not treated but taught with modified lecture method.

The instrument used for data collection was Chemical Equilibrium Students' Interest Rating questionnaire (CESIRQ), Chemical Equilibrium Students Interest Rating questionnaire (CESIRQ) is a 25- interest rating instrument. It is an adapted Likert Scale type of interest inventory developed by Fennema and Sherma (1976). It was used to elicit responses with 
Vol.10, Issue 1, pp. 1-16, 2022

Online ISSN: 2054-636X (Online)

Print ISSN: 2054-6351(Print)

regards to the student interest in chemical equilibrium. The instrument was originally constructed and used for Mathematics students to rate students' interest in the subject. Some structural and statement adjustment were made on the instrument to allow the researcher to use for this study. It is made of 25- items statement forms, with five- response modes which the students are free to choose in accordance to their subjective assessment. The level of agreement or disagreement is measured using the five - response categories which are believed to represent an internal level of measurement. It is a bipolar scaling method measuring either negative or positive response to a statement. This followed the five level responses, strongly agree, agree, undecided, disagree and strongly disagree with numerical value of $5,4,3,2$, and 1 respectively. This instrument was administered as pre-test and posttest.

Lesson plans were used to teach chemical equilibrium for the 4As and 5Es instructional models (experimental group I and II) and control group as conventional strategy. The lesson plans contain behavioural objectives, previous knowledge, teachers' activities, students' activities, evaluation, summary/conclusion and assignment. The plans for the three groups were the same except for the use of 4As and 5Es instructional models which are the experimental groups respectively.

The instrument was validated by three experts, one expert in Science Education, and one in Mathematics Education, Benue State University, Makurdi, and an experienced B.SC (Ed) Chemistry teacher at the Senior Secondary School level. A request for validation of instruments was given to the validators and validation forms. The experts' advice was sought in terms of adequacy of instruments in soliciting the desired response, relevance of instruments to the purpose of the study, structure and grammatical construction of the instruments. Their comments were that the instruments are appropriate and capable of achieving its objectives; items conform to the subject matter, readable, not ambiguous and address the scope of the study.

Lesson plans developed by the researcher for the study are based on the use of 4As and 5Es instructional models for the experimental groups and modified lecture method for the control group were also assessed by these same validators. Their advice was sought in terms of content relevance, clarity of terms, study duration, and logical presentation. Their criticisms, comments and suggestions were used to adjust the lesson plans for the students.

A trial test was carried out on 89 subjects from three senior secondary schools that offered chemistry, which were not part of the sampled schools for the main study. The students were trial- tested and their scores recorded and used to calculate the reliability coefficient in which CESIRQ is 0.70 using Cronbach alpha coefficient . Three chemistry teachers from selected schools for trial testing were trained to teach the two experimental and a control groups respectively. The lesson plans prepared by the researcher based on the concepts of chemical equilibrium were used for teaching by the research assistants for four weeks before the test. The experimental groups were taught using 4As and 5Es instructional models while the control group was taught in the class with charts and chalkboard illustrations. The students were assessed using CESIRQ which comprises 25-items statement. 
Vol.10, Issue 1, pp. 1-16, 2022

Online ISSN: 2054-636X (Online)

Print ISSN: 2054-6351(Print)

This research work involved six intact classes for two experimental groups and one control group. Research assistants were trained to help with data collection. The research assistants were teachers selected from those sampled schools, four assistants for the experimental groups and two assistants for the control group. The data collected were subjected to statistical analysis in order to answer the research questions and test the research hypotheses. The data to answer the research questions and test the research hypotheses were obtained for Chemical Equilibrium Student Interest Rating Questionnaire (CESIRQ).

The pre-test was first administered to the two experimental groups and control group to determine the entry level of the students who participated in the study. The experimental group I were taught using 4As instructional model, experimental group II were taught using 5Es instructional model while the control group were taught using modified lecture method. At the end of the six weeks of teaching the concept of chemical equilibrium, the three groups were post-tested to determine the effects of the two instructional models (4As and 5Es) and the modified lecture method.

Mean and standard deviation were used to answer the twelve research questions while Analysis of Covariance (ANCOVA) was used to test the twelve research hypotheses at 0.05 level of significance. The results of the data analysis and interpretation are presented according to the research questions and hypotheses formulated for the study.

\section{Research Question one}

What are the mean interest ratings of students in Chemical equilibrium when taught using 4As, 5Es instructional models and those taught using modified lecture method?

Table 1: Mean Chemical Equilibrium Interest Rating and Standard Deviation of Students Taught Using 4As, 5Es Instructional Models and Modified Lecture Method.

\begin{tabular}{|c|c|c|c|}
\hline Group & Pre-CESIRQ & Post-CESIRQ & Mean Gain \\
\hline Mean & 1.43 & 2.46 & 1.03 \\
\hline 4As Instructional Model $\mathrm{N}$ & 63 & 63 & \\
\hline Std. Dev & .50 & .56 & \\
\hline Mean & 1.45 & 2.68 & 1.23 \\
\hline 5Es Instruction Model & 64 & 64 & \\
\hline Std. Dev & .50 & .47 & \\
\hline Mean & 1.40 & 1.70 & 0.30 \\
\hline Modified Lecture Method N & 67 & 67 & \\
\hline $\begin{array}{r}\text { Std. Dev }\end{array}$ & .50 & .55 & \\
\hline
\end{tabular}

Table 1 reveals that the mean chemical equilibrium students' interest rating scores using 4As instructional model is 1.43 with standard deviation of .50 in the pre-test and 2.46 with standard deviation of .56 in the post-test. The mean chemical equilibrium students' interest rating using 5Es instructional model is 1.45 with standard deviation of 0.50 in the pre-test and 2.68 with standard deviation of 0.47 in the post-test while that of modified lecture method is 1.40 with standard deviation of 0.49 in the pre-test and 1.70 with standard deviation of 0.55 during the post-test. The mean gain of chemical equilibrium students' 
Vol.10, Issue 1, pp. 1-16, 2022

Online ISSN: 2054-636X (Online)

Print ISSN: 2054-6351(Print)

interest rating using 4As instructional model is 1.03 , 5Es instructional model is 1.23 and 0.30 for those students taught using modified lecture method.

\section{Research Question Two}

There is no significant difference between the mean interest rating scores of male and female students taught chemical equilibrium using 4As instructional model.

Table 2: Mean Chemical Equilibrium Interest Rating and Standard Deviation of Male and Female Students Taught Using 4As Instructional Model.

\begin{tabular}{lcccc}
\hline Gender & & PreCESIRQ & PostCESIRQ & Mean Gain \\
\hline \multirow{3}{*}{ 4As Male } & Mean & 1.4815 & 2.1111 & 0.630 \\
& $\mathrm{~N}$ & 27 & 27 & \\
& Std. Deviation & .50918 & .42366 & 1.028 \\
Mean & 1.3611 & 2.3889 & \\
4As Female & $\mathrm{N}$ & 36 & 36 & \\
& Std. Deviation & .48714 & .54917 &
\end{tabular}

The results as presented in Table 2 reveals that the mean interest rating of male students taught chemical equilibrium using 4As instructional model is 1.48 with standard deviation of .501 during the pretest and 2.11 with standard deviation of .42 in the posttest, and a mean gain of .0630. The mean interest rating of female students taught chemical equilibrium using 4As instructional model is 1.36 with standard deviation of .49 in the pretest and 2.39 with standard deviation of .55 in the posttest, and a mean gain of 1.03. The difference between the mean gains of male and female students taught chemical equilibrium using 4As instructional model is 0.97 in favour of female students.

\section{Research Question Three}

What is the difference in the mean interest ratings of male and female students taught chemical equilibrium using 5Es instructional model?

Table 3: Mean Chemical EQuilibrium Interest Rating and Standard Deviation of Male and Female Students Taught Using 5Es Instructional Model.

\begin{tabular}{llclc}
\hline Gender & & PreCESIRQ & PostCESIRQ & Mean Gain \\
& Mean & 1.4000 & 2.6000 & 1.200 \\
4As Male & $\mathrm{N}$ & 30 & 30 & \\
& Std. Deviation & .49827 & .49827 & 1.324 \\
& Mean & 1.4706 & 2.7941 & \\
4As Female N & 34 & 34 & .41043 & \\
& Std. Deviation & .50664 & &
\end{tabular}

The results as presented in Table 3 reveals that the mean interest rating of male students taught chemical equilibrium using 5Es instructional model is 1.40 with standard deviation of .50 during the pretest and 2.60 with standard deviation of .50 in the posttest, and a mean gain 
Vol.10, Issue 1, pp. 1-16, 2022

Online ISSN: 2054-636X (Online)

Print ISSN: 2054-6351(Print)

of 1.20. The mean interest rating of female students taught chemical equilibrium using 5Es instructional model is 1.47 with standard deviation of .51 in the pretest and 2.79 with standard deviation of .41 in the posttest, and a mean gain of 1.324. The difference between the mean gains of male and female students taught chemical equilibrium using 5Es instructional model is 0.124 in favour of female students.

\section{Research Question Four.}

What are the interaction effects between instructional models and gender on students' interest in chemical equilibrium?

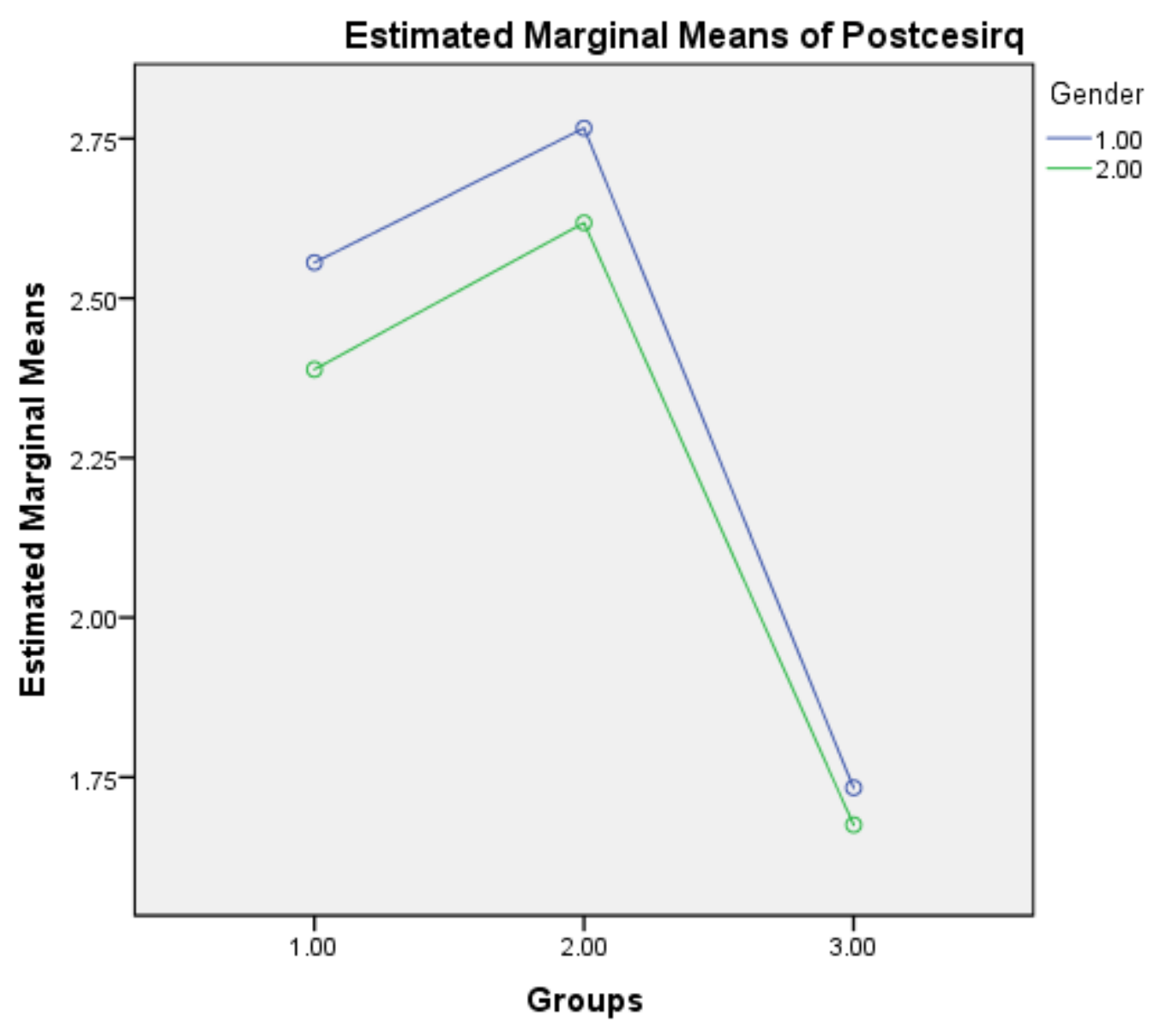

Covariates appearing in the model are evaluated at the following values: Precesirq $=1.4278$

Source: Field Survey, 2021

Fig 1: Plot of Interaction effects of Instructional Models and Gender on Students' Interest in Chemical Equilibrium.

Figure 1 presents a graph of the interaction effect of instructional models and gender on the mean interest rating scores of students in Chemical Equilibrium. The graph marginal lines for gender did not intersect with each other which imply that interaction effect of instructional models and gender does not exist. 
Vol.10, Issue 1, pp. 1-16, 2022

Online ISSN: 2054-636X (Online)

Print ISSN: 2054-6351(Print)

\section{Hypothesis One}

There is no significant mean difference in interest rating of students in chemical equilibrium taught using 4As, 5Es instructional models and those taught using modified lecture method.

Table 4: Two-Way ANCOVA for Mean Interest Rating Scores of Students Taught Chemical Equilibrium using 4As, 5Es Instructional Models and Modified Lecture Method.

Dependent Variable: PostCESIRQ

\begin{tabular}{lllllll}
\hline & \multicolumn{2}{l}{ Type III Sum } & & & Partial & Eta \\
Source & of Squares & Df & Mean Square & F & Sig. & Squared \\
\hline Corrected Model & $30.904^{\mathrm{a}}$ & 6 & 5.151 & 17.402 & .000 & .358 \\
Intercept & 112.652 & 1 & 112.652 & 380.604 & .000 & .671 \\
PreCESIRQ & .063 & 1 & .063 & .213 & .645 & .001 \\
Groups & 28.689 & 2 & 14.344 & 48.463 & .000 & .341 \\
Gender & 1.406 & 1 & 1.406 & 4.751 & .031 & .025 \\
Groups *Gender & .155 & 2 & .078 & .262 & .769 & .003 \\
Error & 55.349 & 187 & .296 & & & \\
Total & 1107.000 & 194 & & & & \\
Corrected Total & 86.253 & 193 & & & & \\
\hline
\end{tabular}

a. $\mathrm{R}$ Squared $=.358($ Adjusted $\mathrm{R}$ Squared $=.338)$

Source: Field Survey, 2021

Table 4 presents the two-way ANCOVA result for mean interest rating of students taught chemical equilibrium using 4As, 5Es instructional models and Modified Lecture Method (MLM). The data in Table 4 showed that the mean difference among the groups was significant $\left[\mathrm{F}_{2,193}=48.463 ; \mathrm{P}=0.000<0.05\right]$. Therefore, the null hypothesis that stated that there is no significant difference in the mean interest rating of students taught chemical equilibrium using 4As, 5Es instructional models and Modified Lecture Method (MLM) was rejected. Hence, there was a significant difference in the mean interest rating among the groups. Meanwhile, the effect size 0.341 as indicated by the corresponding partial eta squared value is considered as a large effect size. This implies that $34.1 \%$ of the difference in the interest rating among the groups was explained by treatments. Hence, the difference in the interest rating among the groups has a large statistical effect size.

Table 5: Bonferroni Post Hoc Comparison for Mean Interest Rating Scores of Students Taught Chemical Equilibrium using 4As, 5Es Instructional Models and Modified Lecture Method.

Dependent Variable: PostCESIRQ

\begin{tabular}{lllcc}
\hline (I)Group & (J) Group & \multicolumn{2}{c}{ Mean Difference (I-J) } & Std. Error \\
Sig. & & & .093 & .000 \\
5Es & MLM & $.665^{*}$ & .093 & .000 \\
4As & MLM & $.990^{*}$ & .093 & .000 \\
4As & 5Es & $-.990^{*}$ & Source: Field Survey, 2021 & \\
& & & Sold
\end{tabular}

Table 5 showed Bonferroni post-hoc comparison for mean interest rating of students taught 
Vol.10, Issue 1, pp. 1-16, 2022

Online ISSN: 2054-636X (Online)

Print ISSN: 2054-6351(Print)

chemical equilibrium using 4As, 5Es instructional models and Modified Lecture Method (MLM). The table result revealed that the mean difference (I-J) between 5Es instructional model and MLM is $.665^{*}$ and this is significant at $p=.000<0.05$. This implies that there is a significant difference in the mean interest ratings between the students taught chemical equilibrium using 5Es instructional model and those taught using MLM in favour of students in 5Es instructional model group. Likewise, the result showed that the mean difference (I-J) between 4As instructional model and Modified Lecture Method (MLM) is .990* and this is significant at $\mathrm{p}=.000<0.05$. This implies that there is significant difference in the mean interest ratings between the students taught chemical equilibrium using 4Asinstructional model and those taught using MLM in favour of students in 4As instructional model group. Similarly, the paired comparison between 4As and 5Es instructional models showed a mean difference of $-0.990^{*}$ and this is significant at $\mathrm{p}=.000<0.05$. This implies a significant difference between 4As and 5Es instructional models in favour of students taught using 5Es instructional model group. This indicates a significant difference in the interest ratings among students taught chemical equilibrium using 4As, 5Es instructional models and Modified Lecture Method (MLM).

\section{Hypothesis Two}

There is no significant difference between the mean interest rating scores of male and female students taught chemical equilibrium using 4As instructional model.

Table 6: Two-Way ANCOVA for Mean Interest Rating Scores of Male and Female Students Taught Chemical Equilibrium using 4As Instructional Model.

Dependent Variable: Postcesirq4As

\begin{tabular}{|c|c|c|c|c|c|c|}
\hline Source & \multicolumn{5}{|c|}{ Type III Sum } & \multirow{2}{*}{$\begin{array}{l}\text { Partial } \\
\text { Squared } \\
.038\end{array}$} \\
\hline Corrected Mode & $.616^{\mathrm{a}}$ & 2 & .308 & 1.169 & .318 & \\
\hline Intercept & 33.689 & 1 & 33.689 & 127.957 & .000 & .681 \\
\hline Precesirq4As & .006 & 1 & .006 & .023 & .880 & .000 \\
\hline Gender & .616 & 1 & .616 & 2.339 & .131 & .038 \\
\hline Error & 15.797 & 60 & .263 & & & \\
\hline Total & 341.000 & 63 & & & & \\
\hline Corrected Total & 16.413 & 62 & & & & \\
\hline
\end{tabular}

a. $\mathrm{R}$ Squared $=.038$ (Adjusted $\mathrm{R}$ Squared $=.005$ )

Table 6 presents the two-way ANCOVA result for mean interest rating of male and female students taught chemical equilibrium using 4As instructional model. The data in Table 6 showed that the mean difference among the groups was not significant $\left[\mathrm{F}_{2}, 62=2.339 ; \mathrm{P}=\right.$ $0.131>0.05]$. Therefore, the null hypothesis that stated that there is no significant difference in the mean interest rating of students taught chemical equilibrium using 4As was not rejected. Hence, there was no significant difference in the mean interest rating among the groups. Meanwhile, the effect size 0.038 as indicated by the corresponding partial eta squared value is considered as a large effect size. This implies that $3.8 \%$ of the difference in the interest rating among the groups was explained by treatments. Hence, the difference in the interest rating among the groups has a large statistical effect size. 
Vol.10, Issue 1, pp. 1-16, 2022

Online ISSN: 2054-636X (Online)

Print ISSN: 2054-6351(Print)

\section{Hypothesis Three}

There is no significant difference between the mean interest rating scores of male and female students taught chemical equilibrium using 5Es instructional model.

Table 7: Two-Way ANCOVA for Mean Interest Rating Scores of Male and Female Students Taught Chemical Equilibrium using 4As Instructional Model.

Dependent Variable: Postcesirq5Es

\begin{tabular}{|c|c|c|c|c|c|c|c|}
\hline \multirow[b]{2}{*}{ Source } & \multicolumn{5}{|c|}{ Type III Sum } & \multirow{2}{*}{\multicolumn{2}{|c|}{$\begin{array}{l}\text { Partial } \\
\text { Squared }\end{array}$}} \\
\hline & of Squares & Df & Mean Square & $\mathrm{F}$ & Sig. & & \\
\hline Corrected Mode & $1.832^{\mathrm{a}}$ & 2 & .416 & 2.027 & .141 & .062 & \\
\hline Intercept & 56.041 & 1 & 56.041 & 272.888 & .000 & .817 & \\
\hline Precesirq5Es & .232 & 1 & .232 & 1.129 & .292 & .018 & \\
\hline Gender & .652 & 1 & .652 & 3.173 & .080 & .049 & \\
\hline Error & 12.527 & 61 & .205 & & & & \\
\hline Total & 481.000 & 64 & & & & & \\
\hline Corrected Total & 13.359 & 63 & & & & & \\
\hline
\end{tabular}

a. R Squared $=.062($ Adjusted R Squared $=.032)$

Table 7 presents the two-way ANCOVA result for mean interest rating of male and female students taught chemical equilibrium using 5Es instructional model. The data in Table 7 showed that the mean difference among the groups was not significant $\left[\mathrm{F}_{2,63}=3.173 ; \mathrm{P}=\right.$ $0.080>0.05]$. Therefore, the null hypothesis which stated that there is no significant difference in the mean interest rating of students taught chemical equilibrium using 5Es was not rejected. Hence, there was no significant difference in the mean interest rating between male and female students taught chemical equilibrium using 5Es instructional model. Meanwhile, the effect size 0.049 as indicated by the corresponding partial eta squared value is considered as a large effect size. This implies that $4.9 \%$ of the difference in the interest rating between male and female students was explained by treatments.

\section{Hypothesis Four}

There is no significant interaction effect between instructional models and gender on students' interest in chemical equilibrium.

The data analysis of Table 1 is used to explain hypothesis 4 . The table presents a two-way ANCOVA for interest rating of students taught chemical equilibrium using 4As, 5Es instructional models and Modified Lecture Method (MLM). Table 1 also presents the interaction effect of instructional models and gender. The data in Table 1 reveals that there is no significant interaction effect of instructional models and gender on the mean interest rating of students in chemical equilibrium $\left[\mathrm{F}_{2,193}=.262 ; \mathrm{P}=.769>0.05\right]$. The null hypothesis is therefore not rejected. Meanwhile, the effect size was 0.003 as indicated by the corresponding partial eta squared value which is considered a small effect size. This implies that only $3 \%$ of the interaction in the interest rating among groups was explained by treatment and gender. Hence, the interaction of instructional models and gender on students' interest rating had small statistical effect size. 


\section{DISCUSSION OF FINDINGS}

This study focused on the effects of 4As and 5Es instructional models on students' academic interest of SSII students in chemical equilibrium in Benue Education Zone C. The study also examined the interaction effect of treatments and gender on students' academic interest in chemical equilibrium. This study revealed that male and female students taught chemical equilibrium using 5Es instructional model had higher interest than the male and female students taught using 4As instructional model. The interest of students taught chemical equilibrium using 5Es instructional model proved that, it is a more student -centered approach than the 4As instructional model thereby influences students to higher interest in chemical equilibrium. Eze, Okeke and Ukeh (2020) showed from their finding that there was significant difference in interest scores of students taught using integrated multimedia in the teaching process and their counterparts in the control group in favour of the experimental group.

The study revealed that the interaction effect between instructional models and gender on the academic performance scores of students in chemical equilibrium is minimal. ANCOVA test revealed that the interaction effect was not significant. This implies that there was no significant interaction effect between instructional models and gender performance scores of students in chemical equilibrium. This finding is in agreement with finding of Agamber, Samba \& Kyeleve (2020) that revealed that the interaction effect between approaches and gender on academic performance of students in Ecology is very minimal. Thus, either 5Es or 4As instructional models can be used successfully irrespective of gender in enhancing students' interest to learn chemical equilibrium and topics that are related. This implies that, there is no need for separation of instructional models for male and female students, since both 5Es and 4As could be used successfully.

\section{CONCLUSION AND RECOMMENDATION}

Based on the findings, the following conclusions were drawn:

The use of 5Es and 4As instructional models had positive effects on students' academic interest in chemical equilibrium. The post test results revealed that 5Es and 4As instructional models has significant effect on students' interest in chemical equilibrium concepts which had already been confirmed by different studies cited in the study. Thus, greater attention should be given to the use of 5Es and 4As instructional models as teaching strategies.

The effect of these instructional models is not dependent on gender. This implies that academic interest in chemical equilibrium is a function of method rather than gender. Both male and female students are capable of interacting, collaborating in classroom activities and finally construct their own knowledge since student interest is the focus of teaching chemistry. These instructional models are effective, learner-friendly and allow active participation of students than Modified Lecture Method which is passive and teachercentered. 
Vol.10, Issue 1, pp. 1-16, 2022

Online ISSN: 2054-636X (Online)

Print ISSN: 2054-6351(Print)

There was no interaction effect between instructional models and gender on students' academic interest in chemical equilibrium. Therefore, there is no need to separate the instructional model for male and female students since both 5Es and 4As instructional models could be used successfully. Based on the findings of these study it is concluded that 5Es and 4As instructional models have greater effects on students' interest in chemical equilibrium concepts than Modified Lecture Method of teaching on senior secondary II students in Benue education Zone $\mathrm{C}$.

The following recommendations are made based on the findings of the study:

1. 5Es and 4As instructional models were found to improve students' academic interest in chemical equilibrium in senior secondary. It is therefore recommended that Government through the Ministry of Education should emphasize the use of 5Es and 4As instructional models in schools through regular supervision.

2. Teacher training institutions such as Faculties of Education, Colleges of Education, and National Teachers' Institute (NTI) should organize training for pre-service teacher in the use of 5Es and 4As instructional models as a policy.

\section{References}

Abande, G. K. (2010). Pedagogical Learning techniques in the $21^{\text {st }}$ Century: Ibadan; Mind Press Ltd.

Agamber, S. T., Samba, R. M.O., \& Kyeleve, J. I. (2020). Improving Students' Academic Performance in Ecology using Science-based Puzzle and Spaced Teaching Approaches. BSU Journal of Science, Mathematics \& Computer Education, 1 (1), $150-158$

Agamber, S. T., Samba, R. M.O., \& Kyeleve, J. I. (2020). Improving Students' Academic Performance in Ecology using Science-based Puzzle and Spaced Teaching Approaches. BSU Journal of Science, Mathematics \& Computer Education, 1 (1), $150-158$

Agogo, P. O., \& Otor, E. E. (2013). Basic issues in the Chemistry of matter. Makurdi: Optimism Press.

Alamina, J. 1. (2016). Fundamental principles of science teaching and learning. Port Harcourt: Votex Publishers.

Ajayi, V. O., Achor, E. E., \& Otor, E. E. (2020). Do predict-explain-observe-explain and Vee Heuristic strategies have the potentials to eliminate gender difference in students' achievement in Organic chemistry? A field report. BSU Journal of Science, Mathematics \& Computer Education, 1 (1), 13-21

Bybee, W. R., \& Pamela, V. S. (2016). The BSCS 5E instructional model: Origins, Effectiveness and Application. Colorado springs, CO: BSCS.

Danjuma, G. S. (2015).Effects of collaborative and competitive learning strategies on upper basic II students' interest and achievement in basic science. Unpublished Ph.D thesis, University of Nigeria, Nsukka (UNN).

Eze, C.U., Okeke, H. K., \& Ukeh, O.B.(2020).Effect of integrating multimedia in teaching and learning of chemistry on secondary schools students' achievement and interest. BSU Journal of science, mathematics \& computer education, 1 (1), 22-32.

Fennema, I., \& Sherman, H. (1976). Attitudes about Mathematics survey. Retrived from www.bc.edu/research/intasac/pdf/opd.bat.studentpost-fall06.pdf2015 
Vol.10, Issue 1, pp. 1-16, 2022

Online ISSN: 2054-636X (Online)

Print ISSN: 2054-6351(Print)

Godspower-Echie, G. \& Ihenko, S. (2017). Influence of gender on interest and academic achievement of students in integrated science in Obio Akpor Local Government Area of River State. European Scientific Journal, 13 (10), 1857- 7881.

Quilez, J. (2019). From chemical forces to chemical rates: A historical/philosophical foundation for the teaching of chemical equilibrium. Science Education. 18, 1203

Onanuga, P. A. \& Saka, A. O. (2018). Trend analysis of students' academic performance in selected Science, Technology, Engineering, and Mathematics subjects in Ogun State Basic Education Certificate Examination (OG-BECE), Nigeria, from 2011 to 2015. A projection for five years. International Council of Association for Science Education, 19 (19), 110.

Olorundare, A. S. (2014). Correlates of poor academic performance of secondary school students in sciences Nigeria. Paper presented at the International Institute for Capacity Building in Higher Education, Virginia State University, Virginia, USA. $20^{\text {th }}-31^{\text {st }}$ June, 2014.

Olorunyomi, A.S. (2013). Effects of experiential teaching method on students' achievement in Chemistry. Unpublished M.Ed dissertation, Ekiti State University, Ado Ekiti.

Ozmen, H. (2008). Determination of students' alternative conceptions about chemical equilibrium; a review of research and the case of Turkey. Chemistry Education Research and Practice, 9, 225 - 233.

Senese, F. (2013). Introduction to Chemistry. Retrieved on $13^{\text {th }}$ March, 2019 from http://www.antoine.frostburg.edu/chem.pdf

Vygotsky, L. S. (1978). Mind in society. The development of higher psychological process. Cambridge; Harvard University press.

The West African Examinations Council. (2011 - 2017). Chief Examiners' Report May/ June. Lagos: WAEC Publishers. 